\title{
PRESERVATION ISLAND, FURNEAUX GROUP: TWO HUNDRED YEARS OF VEGETATION CHANGE
}

\author{
by Stephen Harris and Helen McKenny
}

(with two tables, one text figure, nine plates and an appendix)

Harris, S. \& McKenny, H., 1999 (31:x): Preservation Island, Furneaux Group: Two hundred years of vegetation change. Pap. Proc. R. Soc. Tasm. 133(1): 85-101. https://doi.org/10.26749/rstpp.133.1.85 ISSN 0080-4703. Parks and Wildlife Service, Department of Primary Industries, Water and Environment, GPO Box 44A, Hobart, Tasmania, Australia 7001.

Preservation Island was the first area south of Sydney to experience the impact of European settlement. A recent survey of the vegetation resulted in the inventory of 140 plant species, 49 of these being introduced to the island. Ten vegetation types were mapped, some of these being disturbance disclimax communities. The island has a flora typical of many of the Furneaux Outer Islands. Since 1797, Allocasuarina verticillata, once the likely dominant tree on the island, has been depleted almost to extinction and grassland with a high proportion of exotic species has expanded to cover more than a third of the island. Exotic species propagules have been associated with human activity on the island but also with birds and by sea drift. The high levels of natural and human-related disturbance have encouraged establishment of introduced plants. Some obligate-seeding species on the island have been reduced to either precariously low numbers (Acacia ?genistifolia) or extinction (Callitris rhomboidea) by a high fire frequency.

The biological productivity of the island was high at the time of initial human settlement because there was an extremely large muttonbird rookery, penguins, macropods and other animals. Scrub and low closed forest were more extensive. Most of the biological capital was exhausted within 30 or 40 years. The significance of the island in post-contacr Australian history means that more historical remarks are recorded than would otherwise be expected for such an isolated place.

Key Words: Flora, vegetation, Furneaux Group, Bass Strait, island, human impact, biogeography, conservation, management, weeds, seabird rookery, environment history

\section{INTRODUCTION}

Preservation Island comprises 182 ha and is one of a small group of islands outside the western entrance to Armstrong Channel in the Furneaux Group. It is low and relatively flat, rising to only about $26 \mathrm{~m}$ above sea level. This island occupies a significant place in Australia's European history (Jetson 1996), resulting from the wreck of the Sydney Cove between Preservation and Rum Islands in 1797, prior to the discovery of Bass Strait. The encampment of survivors lasted for several months, and their evacuation led to the discovery of fur seals in the Straits (Collins 1802). The islands were to change dramatically from then on. The significance of the Sydney Cove in Australian history is discussed by Cumpston (1973), Fowler (1980) and Nash (1996).

Preservation Island has been more or less continuously used as a grazing island for nearly 200 years, although it has only been intermittently occupied by people over this time. Other than about 60 head of cattle being grazed on the island at present, there are no introduced grazing animals, and the original macropods on the island have become extinct. A sealer named Munro lived on the island for a number of years, and Maclaine of Clarke Island leased the island for grazing for several decades. The island has had many prominent visitors. For example, Captain Baudin and some of his officers and crew spent some time on the island and have left written records of their impressions. Commander J.L. Stokes in the HMS Beagle also spent some time on the island.

The island comprises mainly Crown land. There is a private freehold block of 20 ha, and the present owners, the Preservation Island Unit Trust, hold a lease on the Crown land. The southeastern portion of the island (10 ha) is part of the Sydney Cove Historic Site, which was proclaimed under the National Parks and Wildlife Act 1970 by virtue of Statutory Rule No. 55 of 1977 . The funding available for rehabilitation of the natural environment, through the Commonwealth's Natural Heritage Trust programme, has inspired a new focus on the outer islands of the Furneaux Group, which are known to have high nature conservation values as well as a long history of degradation by human activity. Preservation Island is an ideal case study, where the nature and magnitude of change can be assessed. The island exhibits the results of more than two hundred years of European impact on its vegetation. It is a confined and clearly identifiable area to which we can attribute a long span of recorded observations.

The Outer Furneaux Islands are of biogeographical interest (e.g. Hope 1972, Hope et al. 1973), but human impacts on their floras vary throughout the Group. The specific aims of this study were to document the vegetation and flora of the island, and its conservation status and biogeographic relationships; also to examine the impacts of human use of the island on the vegetation, and to make recommendations for improving the condition of the native vegetation.

\section{METHODS}

This study is based on three visits to the island. The first two, in 1979 and 1987 (by SH), were for brief botanical reconnaissance; the third was an expedition on 24-26 March 1999 , when more detailed work was carried out by both authors.

(1) The photocommunities were first directly mapped onto a black and white aerial photograph, dated 27 November 1993, which had been enlarged to 1:10 000 scale. 
Photocommunities were areas of uniform texture and tone. (2) Several informal transects were chosen to enable all the perceived vegetation types to be sampled.

(3) The full range of vegetation was sampled by $29100 \mathrm{~m}^{2}$ plots located using the "subjective without preconceived bias approach" of Mueller-Dombois \& Ellenberg (1974) in the range of vegetation types. At each plot, a list of all vascular plant species was made. Percentage cover of the dominant species in each stratum was noted, as well as vegetation structure following the style of Specht (1970). Topographic, substrate and locality information was also collected. Data sheets have been bound and lodged in the library of the Department of Primary Industries, Water and Environment, Hobart.

(4) Other observations along the transects were used to supplement the plot information and assist in interpreting the processes influencing the vegetation.

(5) The boundaries of photocommunities were checked and adjusted after ground truthing and used to compile the vegetation map. An aerial photograph dated 22 February 1986 was used to assess visible changes in vegetation during the period 1986-93.

(6) Floristic communities were identified by hand-sorting of the species lists and were compared with those listed in Kirkpatrick et al. (1995) to assess reservation status.

(7) Plant nomenclature follows Buchanan (1999). Conservation and reservation status of species was assessed against published lists and the schedules to the Tasmanian Threatened Species Protection Act 1995.

(8) A search of the historical literature and sources was made to collect information that would contribute to an understanding of the past vegetation pattern.

(9) One of us ( $\mathrm{SH}$ ) has visited all vegetated islands in the Furneaux Group, enabling us to make comparisons between Preservation Island and others in the Group.

\section{PHYSICAL DESCRIPTION: GEOLOGY, SOILS AND CLIMATE}

The island is formed of medium to coarse-grained Devonian granite with some remnant calcarenite exposed on the sheltered parts of the shoreline. Windblown sand occurs on the southeastern side of the island.

The nearest climate station relevant to Preservation Island is at Swan Island, about $30 \mathrm{~km}$ to the southeast. Swan Island records an annual average rainfall of about $616 \mathrm{~mm}$, with the highest monthly falls during winter. Average summer minimum and maximum temperatures are $14.6^{\circ} \mathrm{C}$ and $20^{\circ} \mathrm{C}$ respectively; the average winter minimum and maximum are $8.2^{\circ} \mathrm{C}$ and $12.8^{\circ} \mathrm{C}$ respectively. Local records on Preservation have been used to suggest an annual rainfall average of only $150 \mathrm{~mm}$ (Jetson 1996), and an annual average of $468 \mathrm{~mm}$, which is predicted by BIOCLIM modelling, still puts the rainfall in the driest part of the Furneaux Islands. The climate is classed as Mediterranean type. Winds are persistent, predominantly westerly and often very strong.

\section{HISTORICAL ACCOUNTS OF THE VEGETATION AND HABITAT}

An analysis of historical observations on the vegetation of Preservation Island and of events that might have shaped the vegetation is important.

The first European contact with the island was on 8 February 1797, when the survivors of the Sydney Cove shipwreck landed safely on the island and pitched their makeshift tents, according to Cumpston (1973) "close to a tufted grassy patch full of burrows". The first stock was landed on the island, namely a mare, a cow, some fowls and some pigeons. These would have had no significant impact on the flora of the island. Cumpston (1973) also claimed that "fires to cook the rice were only kept alight with difficulty". This is not because of any apparent shortage of firewood but because of the rain and strong winds. After news of the wreck reached Sydney, the authorities feared the islands could attract deserting convicts as "it was already well known that the island [Preservation] abounded in birds and kangaroos" (Cumpston 1973).

It is difficult to reconstruct the vegetation at the time of the Sydney Cove wreck. The impact of the survivors during their several months stay may have been considerable. Depletion of macropods and deliberate and accidental fires would have been probable early impacts.

Two stone lookout structures, likely relics of the Sydney Cove survivors (M. Nash, pers. comm.) and sited so as to give unimpeded $360^{\circ}$ views of surrounding waters (e.g. pl. 1), occur on the island. It is assumed that the views from these structures were not impeded by tall vegetation. On the higher ridge of the island, therefore, the vegetation may not have exceeded 4 or $5 \mathrm{~m}$ height at most. Certain vantage points were visible from the sea because Flinders (1801) wrote:

When coming from the westward to Preservation Island, the island is hid under the higher land of Clarke's Island. Lumps of white rock first appear upon it, and upon Night Island.

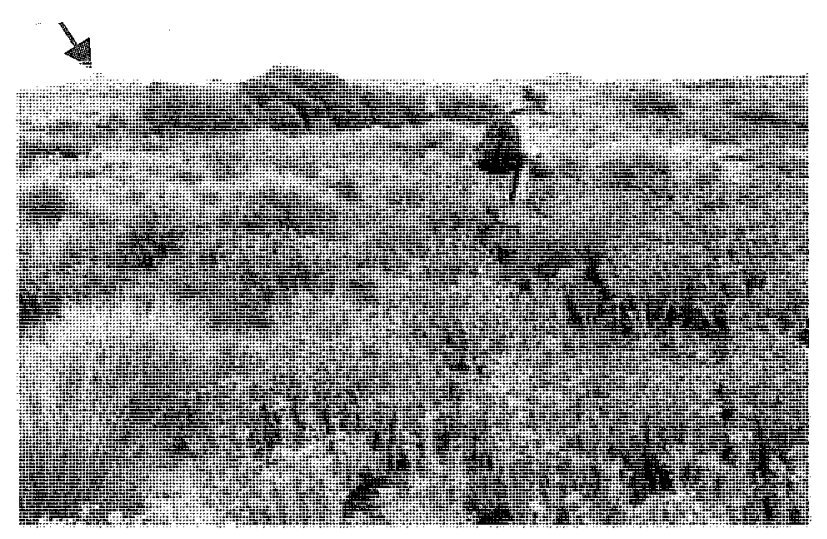

PLATE 1

The figure is standing at the inward margin of a patch of Euphorbia paralias which has colonised a rear-dune blow out on the west coast. The bushes in the background amidst the Poa poiformis grassland are boxthorns (Lycium ferocissimum). Austrostipa stipoides occurs in the left foreground. One of the old constructed lookouts on the island is visible on the horizon in the left distance. 
Flinders would have been referring to guano-stained tors and rocks.

Cumpston (1973) reported that when he left Preservation Island,

Captain Hamilton [from the Sydney Cove] left in the house two hens sitting upon eggs, some breeding pigeons and a bag of rice. He reported that good fresh water was collected in certain seasons in small pools on swampy land near the east end of Preservation Island. The water that drained in a small rill was at first used by the crew, but was thought to have a deleterious quality from the deaths that occurred amongst the crew after drinking it.

Two observations from Nicholas Baudin (Cornell 1974) indicate some more substantial vegetation on Preservation Island. On 10 March 1802, Baudin noted in his journal:

The skipper of this schooner also gave me some information concerning good anchorages in the Furneaux Group and especially off the island that the English have named Preservation Isle, where, according to them, wood and water are easily obtainable.

Baudin (Cornell 1974) made a further reference to the vegetation of the islands on 17 March:

The Furneaux Islands at the entrance to the strait appear bare of trees and even of greenery (or rather, one sees very little of it), but further in, they are well wooded and pleasant."

From the corvette Naturaliste, seaman Brevedent reported in his journal (cited in Plomley 1983) a landing on Preservation Island on 13 March 1802. He accompanied geographer Faure, botanist Leschenault, and mineralogist Bailley. Plomley describes how

... they found the wreckage of a ship of 200-300 tons, and huts made of branches tied together with cordage. On the island they found eggs in great quantity, as well as penguins, crows and kangaroos.

\section{Baudin claimed (Cornell 1974) that}

On Preservation Island particularly, where I stayed for three days, the birds often contended with us by pecking for a place around the fires we had kindled to dry our clothes...

About 1810 , the island was settled by a sealer named Munro, who is mentioned in some usefully explicit remarks about the island given by Campbell in his memoir of 1828 :

Preservation Island is low and sandy. The length is about 3 miles and the average width is about $1 / 2$ of a mile. Munro ... has his residence on the east end fronting Cape Barren Island.

... The original name of the island was "Mutton Bird Island" from its being almost covered with these birds, who build their nests in the ground so as almost to cover the entire surface of the land. Wood grows on the west end of this island of the kinds common to Van Diemen's Land, but principally she-oak. Excepting the western extremity, the other parts of the island are almost free from trees or brush wood.

... Water is procured from a small lake or lagoon, on the east end, which is generally covered with ducks and teal.
The meaning of the term "brushwood" is implicit in Flinders" (1801) journal when he wrote of the Furneaux Islands:

As far as my particular knowledge of the islands extends, their surface is bare rock, in part; or sand which is covered with brush wood; or swamps, in which small trees grow. The brush is very often impenetrable; sometimes growing to a considerable height, and sometimes creeping along the ground; the tall brushwood is found in the inner and eastern parts of the islands, and the scrub on the western outskirts: a proof of the strength and prevalence of westerly winds.

There is no direct evidence for sealing being carried out on Preservation Island, but the island became a "crossroads" for traffic associated with sealing and other activities in the early history of Bass Strait (Kostoglou 1996). By 1830, the tree cover had been depleted to the extent that G.A. Robinson noted in his diary for 9 November 1830 (Plomley 1966):

There is no wood on Preservation Island and $M$ has to fetch it all from Cape Barren.

In the 1830 s and 1840 s, there were a number of recorded visits by, amongst others, George Augustus Robinson, Commander Stokes and officers of the Beagle, and the Quaker missionaries, Backhouse and Walker. Collectively, their comments provide interesting clues as to the nature of the evolving vegetation. On the 8 October 1832 , Backhouse and Walker (Plomley 1987: 221-222) reported that they:

... visited the establishment of James Munro. ... His hut is built of branches, and the intervening spaces filled up with grass and rushes. He has a piece of ground paled round as a garden, in which he grows vegetables of various kinds, and a second piece on which he grows corn, etc.

One of the men named John Hughes walked with us to the western part of the island, which is grassy, with here and there suffructicose plants, upon a light soil. ...The burrows of these birds are so close to one another that one is in constant danger of breaking into them at every step over many acres of ground.

We saw one of those formidable animals (snake) more than five feet long, and gave it a blow which made it rear its head with threatening aspect, but it took refuge in a neighbouring hole, and as the only switch we could raise was a feeble one of Correa alba, we did not think it expedient to repeat the blow. ... There are no trees on the island, nor is there any tall scrub except a few tea-trees about J. Munro's house.

A species of Lavatera (L. plebia) resembling L. arborea was in flower on the slopes down to the shore, on which was also plenty of Polygonum adpressum (the Macquarie Harbour grape) and abundance of nettles of very powerful sting.

J. Munro has a number of pigs and goats and fowls upon Preservation Island ...

The observation that goats were present on the island is important for the impact that they may have had on the vegetation. Their impact, particularly on island floras, has been well documented (Parkes et al. 1996). Moreover, Begg \& Begg (1979) gave an unsourced quote (possibly Boultbee's Journal) that James Munro had "upwards of 800 goats" on the island. 
In a general observation of the islands passed on a voyage to Big Green Island by way of the Chappell Islands, Backhouse and Walker stated that

Many of the islands are low and grassy ... The herbage on Green Island is very similar to that of Preservation, but more luxuriant.

and further that:

Preservation Island is low and covered in grass, barilla, nettles etc. A large portion of it is burrowed so thickly by muttonbirds that it is difficult, in many places, without breaking at almost every step into their holes.

Of domestic plant introductions, they observed that Munro "also grows wheat, potatoes and other vegetables".

Backhouse was an excellent botanical and natural history observer. The excerpts above are of interest because particular species are mentioned and some important information about the vegetation is included. There is an apparent contradiction between the Backhouse and Walker report and the report by Campbell (1828), who said the woody vegetation was on the westerly end on the island, while other parts were free from trees and brushwood. One possibility is that Campbell mistakenly reversed west and east.

In 1842, when Commander Stokes and officers of the Beagle stepped ashore on the island, he reported (Stokes 1846) that

I found Preservation Island inhabited by an older sealer of the name of James Munro, generally known as the King of the Eastern Straitsmen. Another man and three or four native women completed the settlement, if such a term may be applied. They lived in a few rude huts on a bleak flat, with scarce a tree near, but sheltered from the west by some low granite hills; a number of dogs, goats and fowls constituted their livestock. In this desolate place Munro has been for upwards of twenty-three years.

\section{VEGETATION COMMUNITIES}

\section{Atriplex cinerea Shrubland}

The distinctive vegetation on the muttonbird rookeries comprises 2 ha or $1 \%$ of the island (fig. 1). Historical sources indicate that muttonbird burrows once covered most of the island but after 200 years of stock access to all the island, harvesting and burrow destruction, the area has considerably diminished. It is clear that Atriplex cinerea was a dominant plant on the island at least in the 1830 s and 1840 s.

The vegetation on the rookeries varies slightly but is distinguished either by succulent creepers, such as Carpobrotus rossii and Tetragonia implexicoma, the succulent herb Senecio lautus and the scrambling shrub Rhagodia candolleana or by Atriplex cinerea (pl. 2). On the southern end of the island, extensive areas of the silver-coloured shrub Atriplex cinerea indicate calcareous sands with numerous burrows. Burrow density, however, does not appear to be as high as in rookeries on ungrazed islands. This may explain the low diversity of species. The disturbance species which occur in other rookeries, i.e. Lepidium foliosum, Actites megalocarpa, Lavatera plebeia, are rare or absent. Poa poiformis and Lycium ferocissimum are rare in the rookeries. The tallest vegetation layer of Atriplex cinerea has a patchy cover with an average plant height of approximately $0.3 \mathrm{~m}$; the ground cover species have around $95 \%$ cover.

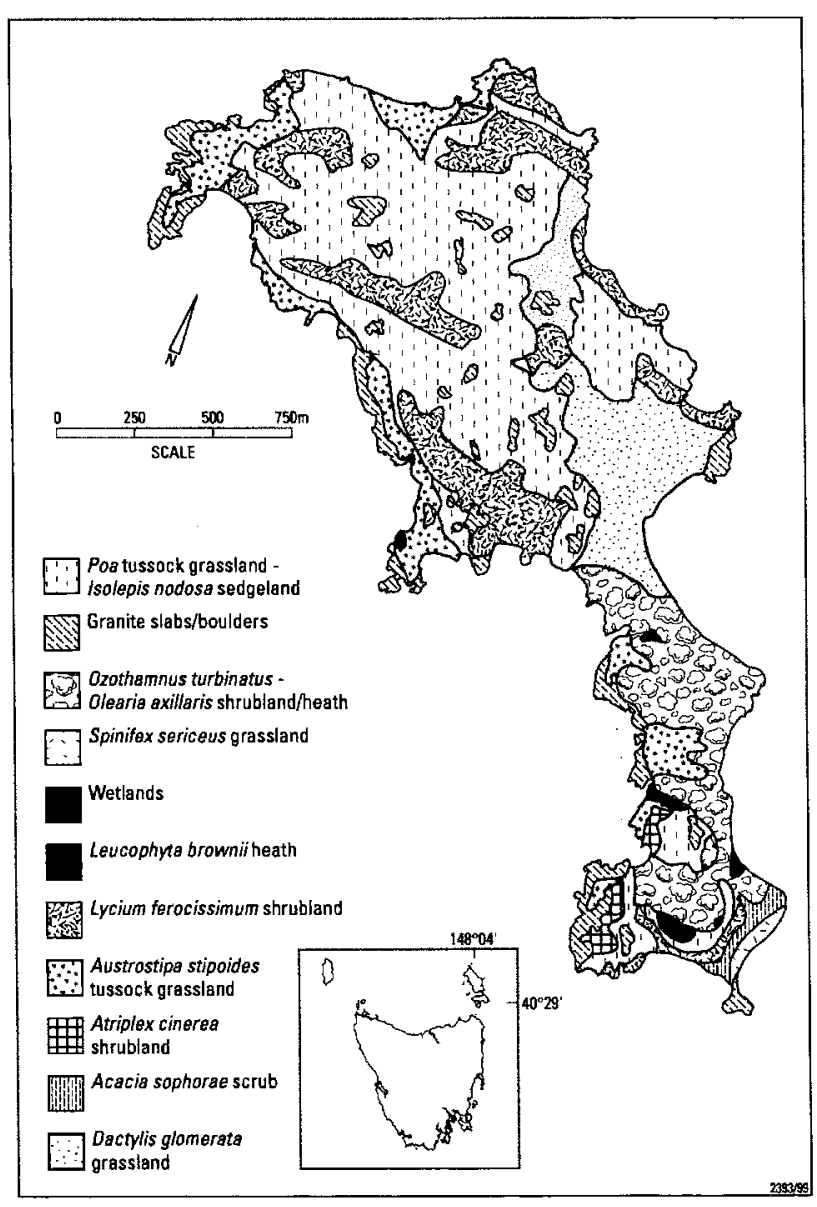

FIG. 1 - Distribution of vegetation types on Preservation Island.

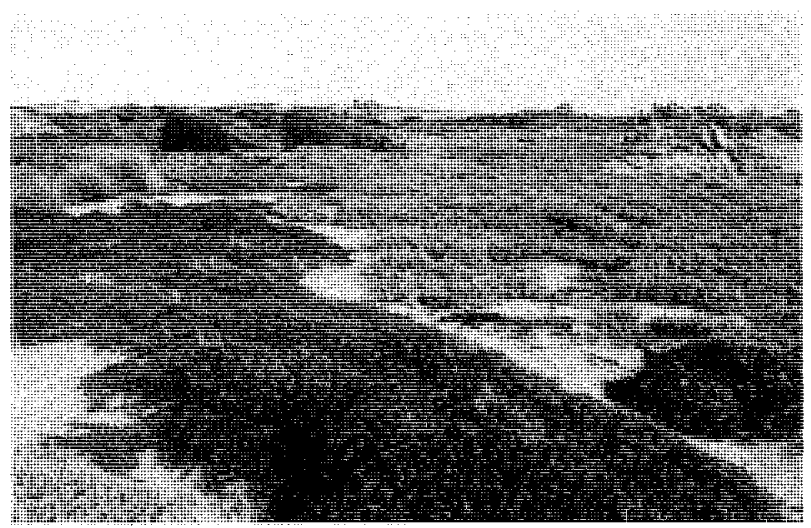

PLATE 2

Atriplex cinerea shrubland on the southeastern coast, bounded by a succulent herbfield of Carpobrotus rossii in the foreground. Note the wind pruned Lycium ferocissimum in the middle distance. 


\section{Ozothamnus turbinatus-Olearia axillaris Heathland}

This vegetation type is predominant on the deep sandy soils at the southern end of the island and occupies 22 ha or $12 \%$ of the area. There is a range of facies in this type. For example, at plot 9 there was the disturbed remnant of a facies, which may have formed a closed heath of $O$ zothamnus and Olearia axillaris but appears to have been destroyed by wind. The inclination of the trunks indicates a strong influence from prevailing winds. Once the closed heath is breached by the wind, the physical damage is great. Other species which occur in this community include Threlkeldia diffusa, Tetragonia implexicoma, Carpobrotus rossii, Apium prostratum and Isolepis nodosa.

The heathland at plot 9 had developed by slow height increment, the rate of this being governed by the mutual protection afforded by the density of the shrubs. As the vegetation is dense, and the foliage which is presented to the wind is planed to an even surface, the salt-laden winds tend to prune any new growth emerging above this surface. Gain in height is only made when sufficient spells of relatively calm weather coincide with a growing period. The vegetation density prevents wind from penetrating the shrub layer.

The same principle explains the "wind row" effect, a pattern which is visible as striations on the aerial photograph. The shrubbery is formed into linear rows aligned with the prevailing wind. Whether there is a shrub row or a wind corridor, or shrub rows of different heights, depends on the features intercepted by the wind at the seaward boundary of the community. The position of a salt-tolerant shrub, a boulder or any other protruding feature will be enough to assist growth of vegetation to the leeward.

Southeast of the hut and close to the track is a tall heathland or low open shrubland, dominated by Lycium ferocissimum, Leucopogon parviflorus, Olearia axillaris and Ozothamnus turbinatus. Diversity is higher, perhaps because the vegetation borders a disturbed open area close to a weed invasion source by the track. Other shrubs or potential shrubs at this site were Correa alba and Pimelea serpyllifolia. Grasses and herbs included Catapodium rigidum, Melilotus albus, Trifolium sp., Bromus diandrus, Epilobium billardierianum, Austrofestuca littoralis, Muehlenbeckia adpressa, Hypochoeris radicata, Lagurus ovatus and Isolepis nodosa. The succulents Senecio lautus, Carpobrotus rossii, Rhagodia candolleana and Tetragonia implexicoma also occur. It is expected that some of these species will be transitory and will not persist once the shrubs assume dominance.

Further upslope on a dune crest, a relatively intact shrubland occurs, which was dominated by Pimelea serpyllifolia, Olearia axillaris and Leucopogon parviflorus. Fewer exotics occur than in the more open disturbed site. Chrysocephalum baxteri is common here and climbs amongst the shrubbery. Myoporum insulare occurs as a low shrub and could potentially dominate as part of a low closed forest with other potential tree species. The other two tree species noted in this community were Allocasuarina verticillata, which was represented by one $4 \mathrm{~m}$ emergent individual (pl. 3), and Bursaria spinosa, represented by some low shrubs, which bore empty seed capsules at the time of our March visit.

This community has a dense cover, which reaches 90 $100 \%$ in some patches, with few herbs and grasses growing in the shaded understorey. Where the shrub layer canopy

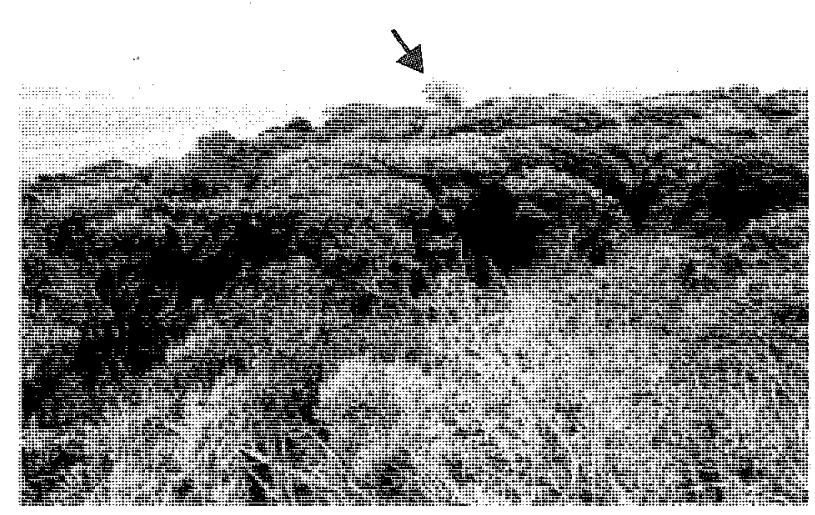

PLATE 3

Ozothamnus turbinatus-Olearia axillaris shrubland gives way in the foreground to a patch of taller closed shrubland with an emergent she-oak (Allocasuarina verticillata) arrowed - the only survivor noted on the island. In 1979 there were three specimens on the island.

is more broken, the ground layer increases its cover up to $70-80 \%$. The community probably retains most of the elements it had prior to European contact, although the rarity of some species which could be expected to dominate and the total absence of others indicate a slow extinction process. Callitris rhomboidea, for example, should probably have occurred here. The structure of the community is likely to have changed considerably since European contact, for instance, cattle tracks are evident throughout.

\section{Native Sand Dune Grassland}

Very small areas dominated by Spinifex sericeus and Austrofestuca littoralis occur around the island, occupying about 1 ha or $<1 \%$ of the island area. The best example is at the southern end of the island, where sand accretion appears to have been taking place. A zone of acid sand, about $20 \mathrm{~m}$ wide or more, is colonised mainly by Spinifex and Austrofestuca. The community is very species-poor and only Actites megalocarpa, Epilobium billardierianum and isolated low shrubs of Olearia axillaris, Pimelea serpyllifolia and Leucopogon parviflorus occur. The total vegetation cover is around $90 \%$, with much of the ground cover being contributed by moss on the older part of the beach.

To landward of this grassland is a dense closed shrubland dominated by Acacia sophorae and Leucopogon parviflorus. The Acacia appears to be slowly spreading out onto the grassland, but the shrubby pioneers appear to be Ozothamnus turbinatus and Olearia axillaris. This zone, with its invading shrubs, is also characterised by hydrophilus mosses on the older sand, whereas in a swathe parallel to and closer to the shore, there is no moss on the sand surface. Euphorbia paralias occurs at the northern end of this beach and numerous seedlings are evident.

\section{Bare Granite Slab and Boulder Communities}

The communities occurring on granite slabs and boulders are distinctive and represent plant assemblages responding to very particular environmental conditions. Hunter (1998) has advocated the separate mapping of such habitats in 
vegetation surveys. They were distinguished in this survey and occupy 13 ha or $7 \%$ of the island.

It seems there are several broad types of granite slab and boulder habitats. Groups of rocks or boulders with high inaccessible crevices provide fire and disturbance-protected niches for some plants. On many of the outer islands of the Furneaux Group, species such as Cyathodes juniperina, Olearia phlogopappa and Alyxia buxifolia occur in such areas. There seems to be a depauperate boulder refugia diversity on this island, perhaps attributable to the long history of human impacts through grazing animals and fires. Goats were known to have been on the island for a long period, at least during the 19th century, and most of this habitat would have been accessible to them. Species observed in the refugial sites amongst boulders are Asplenium obtusatum, Agrostis aemula var. aemula, Myoporum insulare and Lycium ferocissimum.

The other two main habitats associated with granite slabs and boulders are runnels and crevices with skeletal soil, which ate highly susceptible to drought (pl. 4), and skirting communities, where a distinctive community occurs on the periphery of granite slabs. At the periphery, there is a buildup of gravelly detritus, and moisture is available in larger but infrequent amounts through runoff. There is a wide range of microhabitats, but unreliability of moisture is the major limiting factor. The runnel communities are often characterised by shallow soils in rills of varying sizes. In times of rain, these would soak up considerable moisture. The drying out would occur fairly slowly, perhaps impeded by the surficial lag of quartz and feldspar detritus on the surface. Crassula sieberana subsp. tetramera is the most ubiquitous species. Othet plants commonly occurring include Plantago coronopus, Centrolepis strigosa, Hypochoeris radicata, Bulbine semibarbata and Dichelacne crinita. Brachyscome diversifolia is also common. Acacia ?genistifolia, which is uncommon in the surrounding shrubland, is found in crevices. This accords with Hunter's observation (1998) that obligate seeders, which may be disadvantaged by a high fire frequency, can survive in a fire-protected crevice. The species in this community have patchy cover, overall less than $25 \%$, and generally are low growing, reaching a maximum height of $0.1-0.15 \mathrm{~m}$.

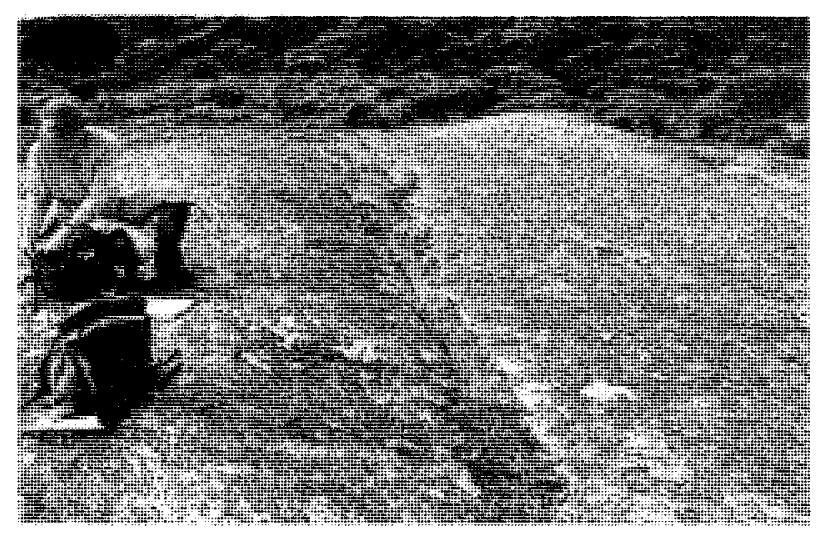

PLATE 4

Granite slabs have distinctive assemblages of plants in crevices and depressions.
The skirting communities vary, depending on particular site circumstances, but commonly there is a strong, simple zonal influence, where the marginal community is dominated by Crassula sieberana subsp. tetramera or Bulbine semibarbata. This specialised niche is defined by the infrequent and unreliable appearance of surface runoff from the granite slab. Otherwise, the habitat is very dry, because the soil is very shallow, no more than $10-20 \mathrm{~mm}$ deep.

\section{Acacia sophorae Closed Scrub}

This vegetation type occurs on stable sand dunes at the rear of the easternmost beach (pl. 5), and comprises only about $1.5 \mathrm{ha}$ or $<1 \%$ of the island. The vegetation is dominated by Acacia sophorae and Leucopogon parviflorus, which have more than $90 \%$ canopy cover and stand at $3 \mathrm{~m}$. The understorey is sparse in terms of species numbers, but patches occur whete Rhagodia candolleana climb through the scrub. Pimelea serpyllifolia, Lepidosperma gladiatum and Poa poiformis form variously scattered or patchy occurrences on the ground. The litter layer is almost $100 \%$ but is no more than $10 \mathrm{~mm}$ over sand, indicating that this vegetation is not very old. The largest Acacia sophorae had a dbh of $0.2 \mathrm{~m}$.

\section{Wetlands, Damp Herbfields, Soaks and Moist Halophytic Grasslands and Herbfields}

A range of specialised habitats is reported and discussed here. Altogether, such habitats probably comprise about 1 ha or $<1 \%$ of the island. The variation in these types is discussed under subcategories. Some subcategories comprise elements of others.

\section{Wetlands}

There are no lagoons or swamps which permanently hold water on the island. The only true swamp is on the southeastern part of the island. Roughly rounded in outline, the site is surrounded by shrubland on stable sand dunes. The

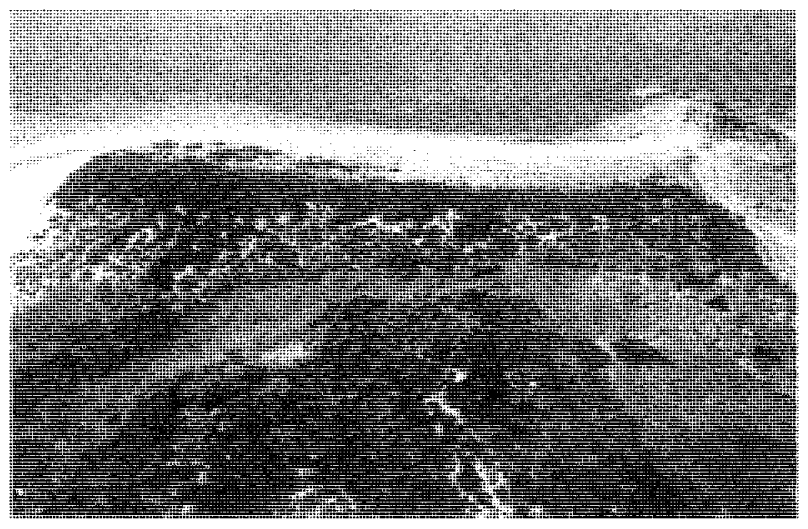

\section{PLATE 5}

The southeastern shore of the island from the air. The beach is accreting, apparently through longshore drift of sand from the left. The dark patch is the Acacia sophorae closed scrub. An intermittent lagoon is visible as a darker patch in the extreme lower right hand corner of the photograph. 
wetland is zoned and comprises an outer zone dominated by Juncus kraussii with abundant Apium prostratum climbing through these. A wide zone occupying most of the wetland is a halophytic herbfield comprising a dense cover of Sarcocornia quinqueflora and Suaeda australis. The central depression had no free surface water but was mainly bare ground with Cotula coronopifolia and Atriplex prostrata. The ground cover is nearly $100 \%$ at this site, with the taller species in general reaching not more than $0.5 \mathrm{~m}$ in height.

\section{Soaks}

These occur around the coast, where groundwater appears out of the interface between granite bedrock and overlying sands or calcarenite (pl. 6). The sand is usually a dark brown indurated layer above the bedrock. The soaks vary in their flow rate, species composition, size and condition, according to whether there is natural or fenced protection from stock, amount of shading, and degree of exposure.

At one fenced soak on the southeastern shore, microtopography varied greatly within a $1 \mathrm{~m}$ range, with Poa poiformis occurring with Trifolium fragiferum, Leucopogon parviflorus and Stipa stipoides on the higher parts. No aquatic species were observed where the water had been artificially ponded by a small concrete dam, but a dense halophytic herbfield dominated by Sarcocornia quinqueflora occurred alongside patches of Isolepis cernua. Other species present included Apium prostratum, Disphyma crassifolium, Distichlis distichophylla, Vellereophyton dealbatum, Hordeum murinum ssp. glaucum, Plantago coronopus, Mimulus repens and Lobelia alata. Below this dam, outside the fenced area, there was abundant Chenopodium pumilio. Isolepis cernua, Disphyma crassifolium, Carpobrotus rossii, Apium prostratum and Cotula coronopifolia were present. Vegetation cover is $100 \%$ around the dam in the fenced area and $20 \%$ outside.

\section{Damp herbfields and halophytic grasslands}

These occur on flat depressions close to the shore, often where onshore winds can carry and deposit salt spray. Distichlis distichophylla is the common dominant, sometimes forming dense monospecific carpets. In some areas, Austrostipastipoides occurs on the more exposed areas. Other common species include Sarcocornia quinqueflora, Plantago

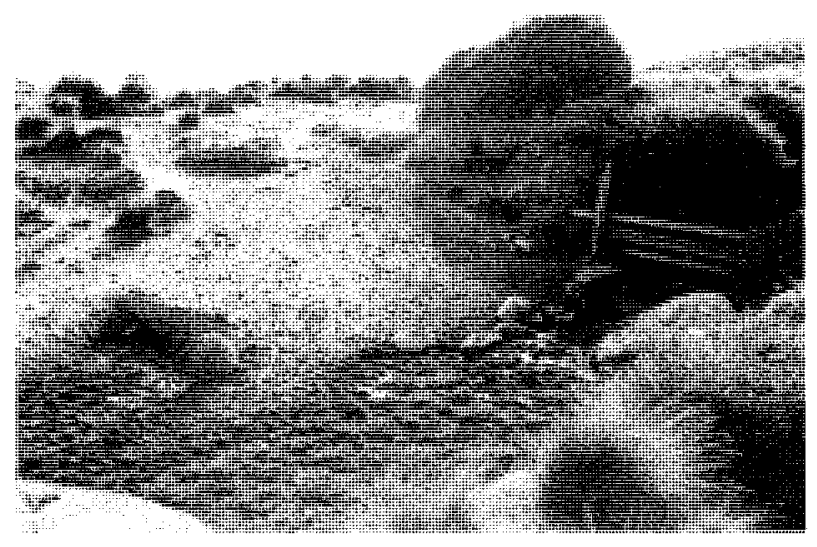

PLATE 6

A fenced offspring on the south coast of the island. Erosion and darnage to the damp herbfield has occurred. coronopus, Isolepis nodosa, Melilotus albus, Dichondra repens, Lobelia alata, Tetragonia implexicoma, Senecio lautus, Cotula coronopifolia, Disphyma crassifolium and Apium prostratum. At plot 10, these were supplemented by the exotics Holcus lanatus, Trifolium sp., Hypochoeris radicata and Anagallis arvensis. The height of this vegetation is less than $0.3 \mathrm{~m}$ and ground cover is $100 \%$.

\section{Coastal Fringe Vegetation}

Preservation Island is low, relatively flat and very exposed, therefore no area escapes maritime influence. Distinct detectable coastal vegetation zones are hardly discernible on the aerial photograph as a mapping community apart from the distinctive Spinifex grassland and the Acacia sophorae scrub on the southern end of the island. Elsewhere, the impact of stock has been extended right to the shore. The circumcontinuity in any zoning that might once have occurred has been disrupted, and now small pockets of predominantly native littoral species occur in areas protected from stock and humans. The exotics Cakile edentula, $C$. maritima and Euphorbia paraliasare the dominant strandline species, and these are especially common on the northern and western shores of the island.

\section{Poa poiformis Tussock Grassland- Isolepis nodosa Sedgeland}

The Poa poiformis tussock grassland and Isolepis nodosa sedgeland communities are regarded as close facies variants and share a similar suite of species. The Isolepis nodosa sedgeland is detectable on black and white aerial photographs as darker, uniformly textured areas, and the circular clonal groups can sometimes be seen. Collectively they are the most widespread vegetation communities, covering 71 ha, or approximately $39 \%$ of the island (pl. 7). Many species are common to both vegetation types, including Bromus, Plantago coronopus, Melilotus albus, Trifolium sp., Cirsium vulgare, and Acetosella vulgaris. The maximum height of this vegetation is $1 \mathrm{~m}$ where Isolepis occurs but is more commonly

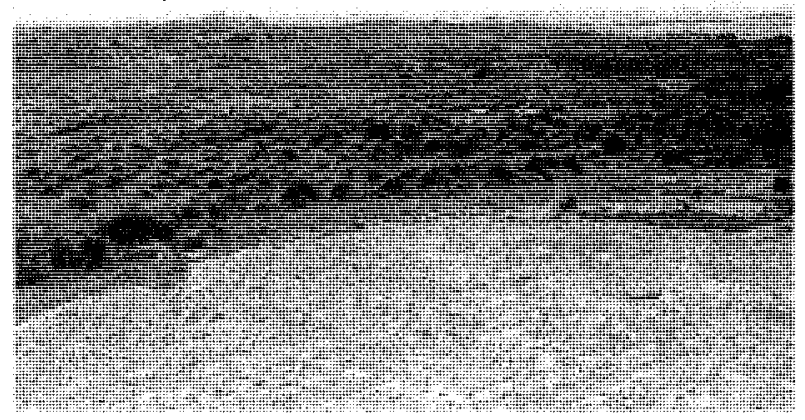

PLATE 7

Looking east across the island. Poa poiformis grassland is the predominant vegetation visible. Rum Island is in the distant right. 
around $0.3 \mathrm{~m}$. The cover averages about $80 \%$. Both Poa poiformis and Isolepis nodosa are common in most vegetation types across the island.

\section{Austrostipa stipoides Tussock Grassland}

Austrostipa stipoides tussock grassland is most extensively developed at the western extremity of the island, where there is full exposure to onshore westerly winds. Smaller patches occur discontinuously around the more exposed sections of coast, particularly the south coast. Altogether, this vegetation type occupies 18 ha or $10 \%$ of the island. At the western end of the island, the tussocks reach around $1 \mathrm{~m}$ in height and are very dense, but some intertussock spaces occur. There is $100 \%$ ground cover, the species including Gamochaeta purpurea, Melilotus albus, Dichondra repens, Trifolium sp., Plantago coronopus, Tetragonia implexicoma, Rhagodia candolleana, Actites megalocarpa, Dichelachne crinita, Brachyscome diversifolia and Isolepis nodosa. These species rarely share the Austrostipa canopy at $0.6 \mathrm{~m}$ but are found between the tussocks, contributing to a layer at about $0.1-$ $0.2 \mathrm{~m}$ in height. Where the Austrostipa meets the spray zone, the transition is directly to Disphyma crassifolium and Frankenia pauciflora in some highly exposed areas.

\section{Lycium ferocissimum Shrubland}

This mapping community occupies 31 ha or $17 \%$ of the island (pl. 8). The boxthorn generally reaches between 1 and $3 \mathrm{~m}$ in height and remains prevalent in Poa poiformistussock grassland and Isolepis nodosa sedgeland. Shrubs can coalesce to form patches with $100 \%$ cover. There are no co-occurring species which are always associated with Lycium; however, its thorny nature allows plants which would otherwise be heavily grazed to thrive. Examples are Dichondra repens, Chenopodium pumilio and Rhagodia candolleana. Lycium ferocissimum individuals occur throughout the island in all communities except the Spinifex sericeusgrassland and Acacia sophorae scrub.

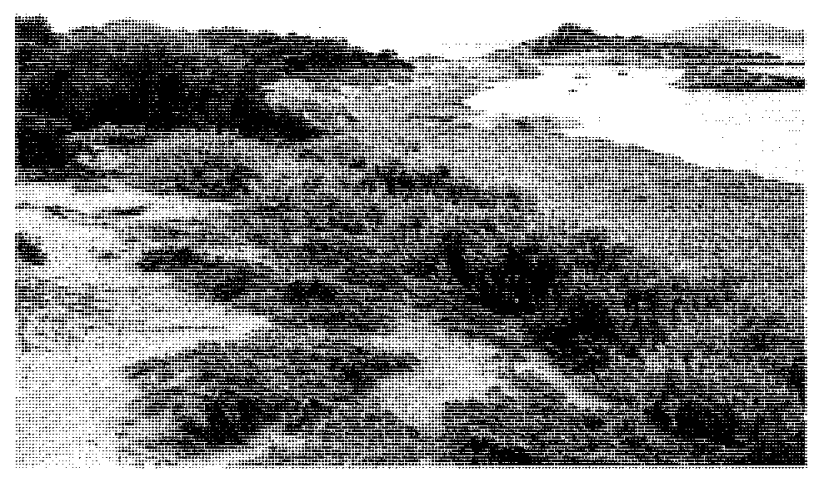

PLATE 8

On the southeast coast, a zone of Atriplex cinerea shrubs gives way to Lycium ferocissimum shrubland. The beach has a heavy clump of sea grass, originating from the Posidonia australis sea grass beds in the shallows offshore.
According to Reg Munro (pers. comm., 7 June 1979), there was no boxthorn on the western part of the island in the early 1950 s, but it spread rapidly throughout the islands, apparently after starlings became established. Extensive areas of boxthorn, evident on the 1986 aerial photograph, have been removed by the present lessees.

\section{Dactylis glomerata Exotic Grassland}

This community occurs on Munro's Flat, where the airstrip and the hut are located (pl. 9). The area is maintained free of tussock for use by aircraft. The total area occupied by the community is 23 ha or $13 \%$ of the island. The grassland is closely grazed and kept slashed. Many of the species occurring in this community are common to Poa poiformis tussock grassland and Isolepis nodosasedgeland. Chenopodium murale is an introduced species favoured by trampled stockyards, but also prone to grazing. It occurs in the fenced compound around the hut and was observed in a fenced area of this community southwest of the hut. This grassland is closely grazed to less than $0.1 \mathrm{~m}$ average height and has a cover of more than $90 \%$.

\section{Leucophyta brownii Heath}

This community occupies less than 1 ha or $<1 \%$ of the island. The Leucophyta may form open or closed heaths. The dominant is tolerant of salt-laden onshore winds and seems also to thrive in areas of active erosion or unstable substrates. One small patch of Leucophyta dominated an old sand blowout and was associated with Zygophyllum billardierei and Threlkeldia diffusa. It also dominates in some small areas on the southern shore. The community has a total cover of only $50 \%$, and is uneven in height up to about $0.4 \mathrm{~m}$.

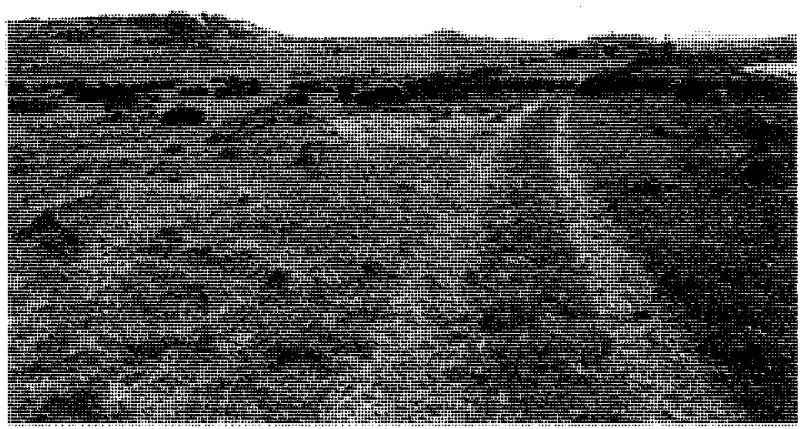

PLATE 9

The Dactylis glomerata dominated exotic grassland looking west towards the hut. The darker patches are Isolepis nodosa. 


\section{THE FLORA}

The vascular flora observed on the island amounted to 140 species from 119 genera in 49 families. Just over one-third (49) are introduced species, a similar ratio as for the whole Tasmanian flora. The Poaceae $(\mathrm{n}=23)$ and the Asteraceae $(\mathrm{n}=22)$ are the best represented families. The next most wellrepresented families are Fabaceae $(\mathrm{n}=9)$ and the Chenopodiaceae $(\mathrm{n}=8)$. There is a high proportion of species which are also characteristic of dry coastal floras in South Australia. For example, in an extensive coastal botanical survey around Spencer Gulf, Kangaroo Island and southeastern South Australia (Oppermann 1996, 1997), species lists were made at 384 quadrats. Sixteen (including 2 exotics) of the 20 most frequently occurring plant species in that survey are also prominent on Preservation Island. This similarity underscores the strong affinity of these islands with the drier South Australian coast. Another similarity is the presence of calcarenite and highly calcareous sands in Bass Strait and on the South Australian coast. Sixtysix percent of the Preservation Island flora overlaps with the total species list from Oppermann (1997) together with species recorded from South Australia's offshore islands by Robinson et al. (1996).

\section{Exotic Species}

The high levels of natural and human-related disturbance have encouraged the establishment of exotic species. Transport of propagules has been through birds, by sea, from stock and from materials and other goods brought in by people.

Some of the introduced species are widespread cosmopolitan plants, which would have been present from soon after European exploration. These include Plantago coronopus, Cakile edentula, C. maritima and Catapodium rigidum. The exotic species comprise plants which would have been accidentally or deliberately introduced in the course of introducing and providing pasture for livestock. These include Bromus, Holcus lanatus and Dactylis glomerata. Continuing disturbance and nutrient concentration would contribute to the persistence of herbaceous weeds, especially in the Poa poiformis tussock grassland - Isolepis nodosa sedgeland. Other exotics are considered aggressive colonisers which pose a threat to the environment. These are Lycium ferocissimum, Cirsium vulgare and Euphorbia paralias.

The spread of exotic species has been occurring since the earliest days of European ships in southern waters. For example, it has been claimed (Heyligers 1987) that species like Cakile maritima and Euphorbia paralias may have spread rapidly around the coast, once introduced into Australian waters in ships ballast. There are many small weeds which are widespread around the southern latitude coasts. For example, on the Crozet Islands in the Southern Ocean, at latitude $46.5^{\circ}$, at least $10 \%$ of the introduced species and congeners representing a very high percentage of the remaining $90 \%$ of Crozet weeds (Carcaillet 1993), also occur on Preservation Island.

Many of the exotic species have been introduced in association with agriculture. Reports of gardens on the island early last century growing wheat, corn and potatoes have left no physical legacy. Marrubium vulgare is a persistent farmyard and 19th-century garden plant, which tends to stay close to its point of origin and seems to be a good indicator of historic sites such as long-gone farm houses and huts. Lycium ferocissimum was probably first introduced to the islands of Bass Strait for windbreak plantings around huts and houses. It has spread throughout all the islands, aided by birds (e.g. starlings) eating the fruit and expelling the seeds over a widespread area. Some islands have become completely infested by boxthorn and it would rapidly overtake Preservation Island without continued efforts to control the population.

Euphorbia paralias is beginning to take a hold on the island (pl. 1). Its distribution and spread in Tasmania have been discussed by Harris \& Davis (1995), Harris \& Kirkpatrick (1996) and Harris \& Balmer (1997). Heyligers (1987) showed how it has spread from Western Australia. Willis (1953) stated that:

Euphorbia paralias is an interesting new record of a littoral, alien species which I found only at one place, viz. the extreme eastern part of the beach on Goose Island Bay (Middle Island) where it was well established amongst driftwood and clumps of Scirpus nodosus. The only other Australian location of this European Sea Spurge would seem to be on the west coast of Yorke Peninsula, South Australia, opposite Wardang Island - perhaps the two widely separated occurrences are linked by the visit of some ship?

It is known that Bruce Bensemann, a former lease holder, planted blue gum seedlings at the site of Munro's garden in the $1970 \mathrm{~s}$, but there was no trace of these at the time of our recent survey. Additionally, Ulex europaeus was recorded from the island in 1987 but was not observed on the recent expedition, causing hope that the rare occurrence has been eliminated.

\section{Species of Conservation or Biogeographic Significance}

There are four species from the island listed on schedule 5 of the Tasmanian Threatened Species Protection Act 1995. These are Frankenia pauciflora, Agrostis aemula var. aemula, Chrysocephalum baxteri and Zygophyllum billardierei. Zygophyllum is confined to calcareous sands on the south side of the island. Frankenia pauciflora is very localised on the northeast coast of Preservation Island. Agrostis aemula var. aemula was observed amongst granite boulders on the northern shore.

Chrysocephalum occurs predominantly on the eastern end of the island in Ozothamnus turbinatus-Olearia axillaris heathland. Threlkeldia diffusa is confined in Tasmania to the shores of Bass Strait. Threlkeldia is locally common, especially in one wind-damaged patch of Ozothamnus turbinatus shrubland. The species is highly susceptible to grazing, and on some of the islands in the Furneaux Group, which have had sheep, its abundance has clearly been reduced to the point where it only survives in sites totally protected from grazing.

A specimen of Lepidium byssopifolium, collected by J. Whinray from Preservation Island, is lodged in the National Herbarium of Victoria (MEL). It is a species which is endangered at both state and national levels. The specimen was confirmed by N. Scarlett on 14 August 1981. Other congeners are more common throughout Bass Strait Islands, particularly in bird rookeries. We note that 
Robinson et al. (1996) recorded the species on Dog Island and Masillon Island, two of the far west coast islands of South Australia.

Plants indicating particular environments are given in table 1. Our observations are consistent with associations reported elsewhere on Bass Strait Islands and coasts.

\section{CONSERVATION VALUES OF THE FLORA AND VEGETATION}

The island has populations of the following species which are highly restricted in Tasmania: Threlkeldia diffusa, Zygophyllum billardierei, Frankenia pauciflora, Chrysocephalum baxteri and Lepidium hyssopifolium (J. Whinray collection).

In a statewide context, the Sydney Cove Historic Site contributes best to the reservation status of Atriplex cinerea shrubland (Kirkpatrick et al. 1995) but is also important (table 2) for having examples of two poorly reserved or unreserved floristic communities.

TABLE 1

Some species strongly associated with particular environments

\author{
Species associated with limestone or calcareous soils \\ Threlkeldia diffusa \\ Zygophyllum billardierei \\ Lagurus ovatus \\ Chenopodium murale \\ Myoporum insulare
}

Species associated with highly exposed rocky shorelines

Disphyma crassifolium

Frankenia pauciflora

Sarcocornia quinqueflora

Leucophyta brownii

Austrostipa stipoides

Species associated with muttonbird rookeries

Atriplex cinerea

Carpobrotus rossii

Brachyscome diversifolia

Species associated with rock slabs and boulder outcrops

Crassula sieberana subsp. tetramera

Microsorum pustulatum

Asplenium obtusatum

Calandrinia calyptrata

Bulbine semibarbata

Dianella brevicaulis

Species of sandy shores

Euphorbia paralias

Cakile edentula

C. maritima

Austrofestuca littoralis

Spinifex sericeus

\section{DISCUSSION}

The most intriguing aspect of Preservation Island's vegetation is the degree to which it has changed since 1797 . To assess change it is necessary to reconstruct the vegetation by using historical evidence or indications drawn from the present components of the flora, and by extrapolating from vegetation on other islands, allowing for differences in size, topographic variation, degree of exposure to the westerlies and the proximity of Preservation Island to larger land areas.

The historical record is patchy, but we know that the extent of the muttonbird rookery was far greater than it is today, while there are conflicting indications as to how wooded the island was. Some observers indicate the island as being covered in barilla, nettles and grass, all short vegetation. Other indications point to a much more wooded island, e.g. the advice to Baudin (his journal 10 March 1802, Cornell 1974) that the island had plenty of wood, the construction of a wooden hut by the Sydney Cove shipwreck survivors (Cumpston 1973).

TABLE 2

Native floristic plant communities recorded on Preservation Island and their conservation status*

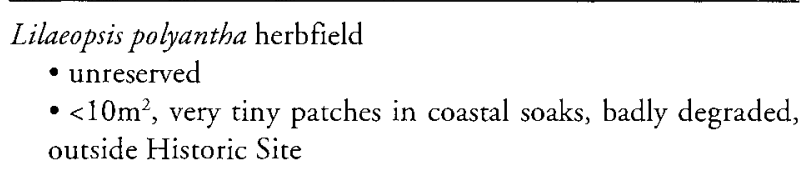

Distichlis distichophylla closed grassland

- poorly reserved

- 0.5 ha, excellent condition

Atriplex cinerea shrubland

- well reserved

- excellent condition, most in historic site

Spinifex sericeus-Austrofestuca littoralis grassland

- well reserved

- excellent condition, newly establishing

Myoporum insulare-Alyxia buxifolia-Correa alba heath

- well reserved

- good condition; a small number of exotic species

Austrostipa stipoides-Disphyma crassifolium tussock grassland

- well reserved

- good condition but accessed by cattle

Leucopogon parviflorus-Lobelia alata-Isolepis nodosa shrubland

- well reserved

- tiny fragments within the coastal fringe zone

* (Kirkpatrick et al. 1995) 
The present composition of the vegetation indicates a few species which could form tall dominants of tall scrub or low closed forest, including Allocasuarina verticillata, Myoporum insulare, Bursaria spinosa, and Leptospermum laevigatum. Apart from Myoporum insulare, the others are now very restricted. She-oak (Allocasuarina verticillata) was a dominant species of the vegetation in the 1820 s but by 1979 only three specimens (one of them dying) were observed, and more recently only one specimen has been observed (pl. 3). All of the above species are obligate seeders which would be disadvantaged by a high fire frequency, i.e. two or three fires in rapid succession would cause their local extinction. It is hardly conceivable that these tree species were not more widespread prior to European contact. There is much more potential suitable habitat on the island.

The extrapolation from other islands is useful. Forsyth Island, which is low and sandy and has been little disturbed, has a shrubby vegetation dominated by Olearia axillaris and Ozothamnus turbinatus with patches of Leptospermum laevigatum and Myoporum insulare up to $5 \mathrm{~m}$ height. It is a similar size to Preservation Island. Adjacent to Forsyth, Passage Island, which is on granite, has dense scrub (potential forest) with trees such as Callitris rhomboidea, Allocasuarina verticillata, Leptospermum laevigatum and Melaleuca ericifolia. The larger islands of the Outer Furneaux mostly have relictual stands or individuals of tree species. Eucalypts are the rarest group, being confined to Big Dog, Prime Seal and the Inner Sister Islands. Myoporum insulare occurs on many of the islands and is capable of forming a tall shrubland. Allocasuarina verticillata, a common component of the island floras capable of forming dense, low, closed, tiny relict stands in fire refugia, is on islands such as Badger, Big Dog and Inner Sister.

Preservation is within both the size range of these islands and the range of proximity to a larger land mass. Intriguing to note is the remnant of a post, protruding from a cairn on the high point on the western end of the island. This was examined in 1987 and appeared to be a spar of Callitris. If this was cut by Stokes' party as part of a trigonometrical survey arrangement, the spar would have been cut from whatever was available at the time. If a driftwood piece had been used, it is hardly likely to have lasted over 150 years. Callitris, if cut green, is likely to last this long, because of the special properties of the timber oils.

From the earliest days of European settlement fires may have been lit to help clear scrub for ease of access to lookout points and mutton bird burrows. The vegetation on Preservation Island is buffeted by strong prevailing winds. If fires were lit, there is a high chance that the winds would drive such fires right across the island, since there is very little topographic impediment. Obligate seeders would have suffered, if fires were months or one or two years apart. Such species would have fared worst on the granite substrate on the larger part of the island, west of the sandy areas. Here soil accumulation resulting directly from granite weathering would have been minimal, mainly resulting from the slow deposition of organic matter. As shrubland grew to scrub, provided there was a sufficient fire-free interval, this build up would have been enough to support closed scrub or low closed forest, with moisture retention being assisted by the shading from the vegetation canopy. Once this vegetation was destroyed by a major fire and the organic soil burned away, the succession to low closed forest would have been very slow and would have relied on a long fire-free interval, perhaps $40-50$ years. However, since it is almost certain that the fire frequency increased dramatically after European contact, this would not have occurred. This assumption of increased frequency is based on archaeological evidence that there were no humans occupying the Furneaux Islands prior to this time (Sim \& Gait 1992). Therefore, the fires occurring during this period could only have been caused by lightning strikes and very rare (Jackson 1999).

On the sandy soils at the eastern end of the island, there would have been more chance of obligate seeders surviving, because of the greater depth of soil and the distribution of seed throughout a large part of the soil profile by bioturbation. This may explain the persistence here of Acacia sophorae (pl. 5), as Kirkpatrick (1993) suggested that this species is readily killed by fire but germinates prolifically afterwards from the store of hard-coated seeds in the soil. There is an analogy between the processes which are likely to have happened on this island and the successional pathways to rainforest in western Tasmania. On quartzites, rainforest is able to exist on humic soils which have accumulated from vegetation through the slow successional path. After a hot fire in which the vegetation and soil have been consumed, a long period is required for the vegetation to proceed to a scrub, let alone to rainforest. On deeper mineral soils, there may be more likelihood of a faster succession.

A clue to the former vegetation of the island is found in a watercolour sketch by Laing in 1831 (reproduced opposite p98 in Plomley 1987) which shows some distinctive slender trees on the skyline, the same skyline which is now devoid of vegetation taller than Poa tussocks. Dismissing these trees as an artist's whimsy would not be consistent with the faithful rendering of the remaining background scene, the shapes and position of boulders for example. A most likely explanation for these trees is that they were remnants of the Bursaria spinosa component of the original scrub/low closed forest. Bursaria spinosa has persisted in grazing areas in other parts of Tasmania long after the rest of the original vegetation has been eliminated. The forms of some Bursaria remnants in pasture clearly correspond very well with the painted images from 1831 .

The tea tree remnants of $>4 \mathrm{~m}$ surrounding Munro's cottage at the time of Laing's painting were likely to be remnants of the original scrub.

Evidence indicates that attrition of tall scrub and low forest occurred rapidly after 1797 . The goats kept by Munro ranged freely and would have wrought destruction on the native vegetation. They are capable of breaking down limbs of tall shrubs. Bursaria spinosa is highly palatable to goats, and the specimens in Laing's painting probably represent remnant individuals of a species formerly more widely spread. Once the vegetation became opened up by fire and other disturbances, the salt-laden westerlies would have made re-establishment very difficult. Preservation Island is one of the more highly modified of the Outer Furneaux Islands. Allocasuarina verticillata is especially targeted by goats (Harris \& Wapstra 1999), so the goats on the island would have had a great impact on this species as well as others. Use of timber for building and for cooking fires would have added to the pressure on trees.

Early land use no doubt led to depletion of soils through burning, stock trampling and subsequent wind erosion, once the vegetation structure was opened up through fire and mechanical damage. The deterioration in soil quantity and extent would have meant ground unsuitable for 
continued occupation by burrowing seabirds, in turn exacerbating the loss of nutrient bound up in the organic horizon of the soil.

If we assume that only the native species now present on the island were the same component as at contact, then obviously significant changes have occurred. Historical observers mention the abundance of barilla, especially in the 1830s. This species is favoured by disturbance and is a common component of seabird rookeries in Bass Strait. It is confined to a few localised patches and has clearly been reduced in parallel with the decline in the once extensive muttonbird rookery. It is clear that an outstanding and remarkable feature of the island in earliest times was the extent of this rookery, which was claimed to cover almost the whole island. Rookeries can be sustained in many vegetation types. In a closed scrub, the birds will travel along pathways on the ground until they reach a suitable launching point. The critical requirement is sufficient depth of soil, although dense growths of Tetragonia implexicoma or Rhagodia candolleana can provide burrows, especially where there is additional protection from a shrub or scrub canopy. Dense old Poa poiformis tussocks would also have been able to provide some burrow opportunities, since they form thick trunks, and the decaying older leaves form deep composting layers which can provide some protection.

Coasts and small islands have their terrestrial biological productivity boosted considerably by shore drift of algal wrack and carrion and through colonies of seabirds; such marine input has been found to produce most of the biomass and energy for islands (Polis \& Hurd 1996). The perimeter to area ratio, for example, is a good predictor of arthropod density on islands that have been studied elsewhere. The importance of the energy input from the sea and seabirds cannot be underestimated for an island such as Preservation Island. The island's inherently low primary productivity, due to the very low rainfall and the low nutrient productivity of the granite soils, has been significantly boosted. The dense scrub and the huge numbers of seabirds occupying the island at European contact represent the accumulation of biological capital over thousands of years. Most of this capital appears to have been depleted in the first thirty or forty years following the discovery of the island.

\section{VEGETATION MANAGEMENT}

Conservation work on Preservation Island is important for the nature conservation values on the island and can also help the condition of other nearby islands. Control or eradication of the populations of Euphorbia paralias and Lycium ferocissimum on the island will reduce the source of propagules for further invasion.

The recommendations for maintaining and enhancing vegetation values, in priority order are as follows:

(1) continuing eradication of boxthorn; the programme being carried out by the Preservation Island Unit Trust needs to be supplemented by efforts from the Department of Primary Industries, Water and Environment on the Historic Site;

(2) removing sea spurge by appropriate methods;

(3) poisoning thistles;

(4) reducing stock impact on coastal soaks and springs by engineering better confined access to water, and by fencing; (5) ensuring stock remain confined to the grasslands;
(6) germination from local seed and then planting of Allocasuarina verticillata and Bursaria spinosa in degraded areas, e.g. around the hut; Callitris rhomboidea, germinated from seed collected on Clarke Island, could also be planted in the grassland and hut zone.

(7) developing a fire management plan; and

(8) maintaining vigilance against new weed introductions; searching the area between the jetty and the hut for gorse, destroying any which are found.

The timetable for carrying out these recommendations and the specific methods for implementing them are being considered in the management plan at present being prepared for the island (Nicholas D'Antoine, pers. comm.)

\section{ACKNOWLEDGEMENTS}

We thank the Preservation Island Unit Trust, whogenerously allowed the use of their comfortable hut. Nicholas D'Antoine of the Trust assisted with information about management of the island. We also thank Mike Pemberton for taking care of the logistical arrangements and Sam Bayley of Flinders Island, Chris Grose, Paul Pohlner and Mike Nash for useful discussion. The Special Projects Section of the Department of Primary Industries, Water and Environment prepared the map. The assistance of Alex Buchanan and Dennis Morris of the Tasmanian Herbarium for species identification is much appreciated. Cathryn Coles of the National Herbarium of Victoria was also very helpful in discussing relevant collections in that institution.

\section{REFERENCES}

BegG, A.C. \& BEGG, N.C., 1979: THE WORLD OF JOHN BOULTBEE. Whitcoulls. Christchurch.

BUCHANAN, A.M., 1999: A CENSUS OF THE VASCULAR PLANTS OF TASMANIA. 3rd edn. Tasm. Herb. Occ. Publ. 6.

CampBell, J., 1828: Account of the group of islands situated in Bass Strait generally known in the charts by the name of Furneaux Islands. Hobart Town August 1828. (ms in Mitchell Library, Sydney).

Carcaillet, C., 1993: Les plantes allochtones envahissantes de l'archipel Crozet, Océan Austral. Rev. Ecol. (Terre Vie) 48: 3-20.

Collins, D., 1802: AN ACCOUNT OF THE ENGLISH COLONY IN NEW SOUTH WALES. VOL. II. (Republished by the Royal Australian Historical Society, Sydney, Fletcher, B.H., Reed, A.H. \& Reed, A.W. [Eds], 1975.)

CORNELL, C. (ED.), 1974: THE JOURNAL OF POST CAPTAIN NICHOLAS BAUDIN. Libraries Board of South Australia.

Cumpston, J.S., 1973: FIRST VISITORS TO BASS STRAIT. Rocbuck. Canberra.

FLINDERS, M., 1801: OBSERVATIONS ON THE COASTS OF VAN DIEMEN'S LAND, ON BASS'S STRAIT AND ITS ISLANDS, AND ON PART OF THE COASTS OF NEW SOUTH WALES; Intended to accompany the charts of the late discoveries in those countries. John Nichols, London.

FLORA ADVISORY COMMITTEE, 1994: NATIVE HIGHER PLANT TAXA WHICH ARE RARE OR THREATENED IN TASMANIA. Edn 1. Species at Risk, Tasmania - flora. Parks and Wildlife Service, Tasmania. 
FOWLER, R.M., 1980: THE FURNEAUX GROUP BASS STRAIT. A HISTORY. Vol. 1. Roebuck.

Harris, S. \& Balmer, J., 1997: The vegetation and flora of Three Hummock Island, Western Bass Strait. Pap. Proc. R. Soc. Tasm. 131: 37-56.

HARRIS, S. \& DAVIS, G., 1995: The vegetation and flora of Deal Island, Kent Group. Pap. Proc. R. Soc. Tasm. 129: 4351.

HaRRIS, S. \& KirKPATRICK, J.B., 1996: The coastal vegetation of northeast Tasmania. Rec. Queen Vic. Mus. 103: 121131.

HaRris, S. \& WapsTra, H., 1999: The impact of feral goats on Tasmanian vegetation. Unpubl. rep. Dep. Primary Industries, Water and Environment.

HeYligers, P., 1987: Strandline plants: invaders from overseas. Wildl. Aust. Spring 1987: 19-20.

Hope, J.H., 1972: Bass Strait, its coasts and islands: a symposium. Proc. R. Soc. Vict. 85(2)

Hope, J.H., Murray-Smith, S. \& Norman, F.T., 1973: Bibliography of Bass Strait 1797-1971. Proc. R. Soc. Vict. 85: 79-116.

HunTER, J.T., 1998: Granite outcrop vegetation of Wilsons Promontory. Vic. Nat. 115(6): 322-325.

JACKSON, W.D., 1999: The Tasmanian environment. In Reid, JB., Hill, R.S., Brown, M.J \& Hovenden, M.J. (Eds): VEGETATION OF TASMANIA. Flora of Australia Suppl. Ser. 8. ABRS: Ch. 2, 11-38.

JeTSON, T., 1996: An island of contentment? A history of Preservation Island. Pap. Proc. Tasm. Hist. Res. Assoc. 43(1): $29-46$.

KIRKPATRICK, J.B., 1993: Dry coastal ecosystems of southeastern Australia. In van der Maarel, E. (Ed.): ECOSYSTEMS OF THE WORLD 2B: DRY COASTAL ECOSYSTEMS AFRICA, AMERICA, ASIA AND OCEANIA. Elsevier, Amsterdam: Ch. 19.

Kirkpatrick, J.B., Barker, P., Brown, M.J., Harris, S. \& Mackie, R., 1995: The Reservation Status of Tasmanian Vascular Plant Communities. Wildl. Sci. Rep. 95/4. Parks and Wildlife Service, Tasmania.

Kostoglou, P., 1996. Sealing in Tasmania Historical Research Project. A report for the Parks and Wildlife Service.

Mueller-Dombois, D. \& Ellenberg, P., 1974: AIMS AND METHODS OF VEGETATION ECOLOGY. Wiley, New York.

Murray-SMITH, S., 1979: MISSION TO THE ISLANDS. The missionary voyages in Bass Strait of Canon Marcus Brownrigg 1872-1885. Cat and Fiddle Press, Hobart.
NASH, M., 1996: CARGO FOR THE COLONY. The wreck of the merchant ship Sydney Cove. Braxus Press, Sydney.

OpPermanN, A., 1996: COASTAL DUNE AND CLIFFTOP SURVEY: PROGRESS REPORT. Stage 1 Nullarbor and North-West Eyre Peninsula. Coastal Management Section, South Australian Department of Environment and Natural Resources.

OPPERMANN, A., 1997: COASTAL DUNE AND CLIFFTOP SURVEY: PROGRESS REPORT. Stage 2 Spencer Gulf, Kangaroo Island, and South East. Biological Survey South Australia, Adelaide.

PARKES, J., HENZELL, R. \& PICKLES, G., 1996: MANAGING VERTEBRATE PESTS: FERAL GOATS. Australian Government Publishing Service, Canberra.

Plomiey, N.J.B. (Ed.) 1966: FRIENDLY MISSION. THE TASMANIAN JOURNALS AND PAPERS OF GEORGE AUGUSTUS ROBINSON, 1829-34.Tasmanian Historical Research Association, Hobart.

PLOMLEY, N.J.B., 1983: THE BAUDIN EXPEDITION AND THE TASMANIAN ABORIGINES 1802. Blubber Head Press, Hobart.

Plomley, N.J.B., 1987: WEEP IN SILENCE. Blubber Head Press, Hobart.

Polis, G.A. \& HuRD, S.D., 1996: Linking marine and terrestrial food webs: allochthonous input from the ocean supports high secondary productivity on small islands and coastal land communities. Am. Nat. 147(3): 396-423.

Robinson, T., Canty, P., MoOney, T. \& Ruddock, P., 1996: SOUTH AUSTRALIA'S OFFSHORE ISLANDS. Australian Heritage Commission, Canberra.

SIM, R. \& GAIT, P., 1992: SOUTHERN FURNEAUX ISLANDS ARCHAEOLOGICAL SURVEY: Stage two of the prehistoric and historic archaeological site recording project in the Furneaux Group, Bass Strait, Tasmania. Tasmanian Environment Centre, Hobart: 6-7.

SPECHT, R.L., 1970: VEGETATION OF SOUTH AUSTRALIA. Government Printer, Adelaide.

STOKES, J.L., 1846: DISCOVERIES IN AUSTRALIA; With an account of the coasts and rivers explored and surveyed during the voyage of HMS Beagle in the years 1827-43. Vol. 1 pp420-427. London: T\&W Boone.

Willis, J.H., 1953: Land Flora. In The Archipelago of the Recherché. Aust. Geogr. Soc. Rep. 1. Part 3a. Australian Geographical Society, Melbourne: 3-35.

(accepted 6 September 1999) 


\section{APPENDIX \\ Higher plant census for Preservation Island}

Vouchers and other records:

$\mathrm{HO}=$ Voucher lodged at the Tasmanian Herbarium, Hobart;

MEL = Voucher exists at the National Herbarium of Victoria, Melbourne.

Conservation status codes (source: Threatened Species Protection Act 1995):

3 = Schedule 3 (Taxa of Flora and Fauna which are Endangered) Threatened Species Protection Act 1995.

$5=$ Schedule 5 (Taxa of Flora and Fauna which are Rare) Threatened Species Protection Act 1995.

Distribution codes: $i=$ introduced to Tasmania (source: Buchanan 1999).

Community types: $1=$ Poa tussock grassland

2 = Isolepis nodosa sedgeland

$3=$ Rookery vegetation

$4=$ Ozothamnus turbinatus - Olearia axillaris heathland/shrubland

$5=$ Spinifex sericeus grassland

$6=$ Bare granite slab and boulder communities

7 = Acacia sophorae closed scrub

8 = Wetlands, damp herbfields, soaks \& moist halophytic grasslands and herbfields

$9=$ Coastal fringe vegetation

$10=$ Austrostipa stipoides tussock grassland

11 = Lycium ferocissimum shrubland

12 = Leucophyta brownii heath

Species abundance codes: $\mathrm{r}=$ rare; $\mathrm{o}=$ occasional; $\mathrm{c}=$ common.

Where Status/

vouch- distri-

ered bution

\section{DICOTYLEDONAE}

AIZOCEAE

Carpobrotus rossit

Disphyma crassifolium

Tetragonia implexicoma APIACEAE

Apium prostratum

Lilaeopsis polyantha

APOCYNACEAE

Alyxia buxifolia

ASTERACEAE

Actites megalocarpa

Arctotheca calendula

Brachyscome diversifolia

B. graminea

Carduus tenuiflorus

Chrysocephalum baxteri

Cirsium vulgare

Conyza spp.

Cotula coronopifolia

Cymbonotus preissianus

Gamochaeta purpurea

Gnaphalium indutum

Helichrysum leucopsideum

Hypochoeris radicata

Leucophyta brownii

Olearia axillaris

Ozothamnus turbinatus

Pseudognaphalium luteo-album

Senecio hispidulus

$\begin{array}{rr}\text { Pigface } & \mathrm{HO} \\ \text { Rounded noon-flower } & \mathrm{HO} \\ \text { Iceplant } & \mathrm{HO} \\ & \\ \text { Sea celery } & \mathrm{HO}\end{array}$

Australian lilaeopsis

Sea box MEL

Coastal sow-thistle $\mathrm{HO}$

$$
\text { Capeweed } \mathrm{HO}
$$

Coastal tall daisy MEL

Grass daisy

Winged slender thistle

$$
\text { Fringed everlasting }
$$

Spear thistle

Billy buttons

Bears ear

Purple cudweed

Tiny cudweed

Satin everlasting Cats ear

Cushion bush

Coast daisy bush

Coast everlasting

Jersey cudweed

Hill fireweed $\begin{array}{llllllllllll}1 & 2 & 3 & 4 & 5 & 6 & 7 & 8 & 9 & 10 & 11 & 12\end{array}$

$12,3,4,5,6,7,8,9,10 \quad 11,12$ 


\begin{tabular}{|c|c|c|c|c|c|c|c|c|c|c|c|c|c|c|c|}
\hline & & Where & Status/ & & & & & Com & imun & ty $\mathrm{T}$ & ypes & & & & \\
\hline & & $\begin{array}{l}\text { vouch- } \\
\text { ered }\end{array}$ & $\begin{array}{l}\text { distri- } \\
\text { bution }\end{array}$ & 1 & 2 & 3 & 4 & 5 & 6 & 7 & 8 & 9 & 10 & 11 & 12 \\
\hline S. lautus & Variable groundsell & $\mathrm{HO}$ & & o & $o$ & $c$ & o & $\mathrm{r}$ & o & & o & o & o & & $\mathrm{r}$ \\
\hline Sonchus oleraceus & Common sowthistle & $\mathrm{HO}$ & $\mathrm{i}$ & & & o & & & & & & & & & \\
\hline $\begin{array}{l}\text { Vellereophyton dealbatum } \\
\text { BRASSICACEAE }\end{array}$ & White cudweed & $\mathrm{HO}$ & $\mathrm{i}$ & o & o & & o & & o & & & & & & \\
\hline Cakile edentula & American sea rocket & & $\mathrm{i}$ & & & & & & & & & o & & & \\
\hline C. maritima & European sea rocket & $\mathrm{HO}$ & $\mathrm{i}$ & & & & & & & & & 0 & & & \\
\hline $\begin{array}{l}\text { Lepidium hyssopifolium } \\
\text { J. Whin ray collection: see te } \\
\text { CAMPANULACEAE }\end{array}$ & Peppercress & MEL & 3 & & & & & & & & & & & & \\
\hline $\begin{array}{l}\text { Lobelia alata } \\
\text { CARYOPHYLLACEAE }\end{array}$ & Angled lobelia & $\mathrm{HO}$ & & $\mathrm{r}$ & & & & & o & & $\mathrm{c}$ & $\mathrm{c}$ & $\mathrm{r}$ & & \\
\hline Cerastium sp. & Chickweed & & $\mathrm{i}$ & & & & & & $\mathrm{r}$ & & & & & & \\
\hline Colobanthus apetalus & Coast colobanth & & & & & & & & $\mathbf{r}$ & & & & & & \\
\hline Polycarpon tetraphyllum & Four-leaf allseed & $\mathrm{HO}$ & $\mathrm{i}$ & $\mathrm{c}$ & $\mathrm{c}$ & c & $r$ & & c & & $\mathrm{c}$ & $r$ & $\mathrm{r}$ & $\mathrm{r}$ & \\
\hline Sagina maritima & Sea pearlwort & $\mathrm{HO}$ & $\mathrm{i}$ & & & & & & & & & o & & & \\
\hline $\begin{array}{l}\text { Silene gallica } \\
\text { CASUARINACEAE }\end{array}$ & French catch-fly & $\mathrm{HO}$ & $\mathrm{i}$ & $\mathrm{r}$ & & & & & & & & & & & \\
\hline $\begin{array}{l}\text { Allocasuarina verticillata } \\
\text { CHENOPODIACEAE }\end{array}$ & Drooping she-oak & & & & & & $r$ & & & & & & & & \\
\hline Atriplex cinerea & Grey saltbush & $\mathrm{HO}$ & & & & c & & & & & o & 0 & & & \\
\hline A. prostrata & Mat saltbush & & $\mathrm{i}$ & & & & & & $\mathrm{r}$ & & 0 & & & & \\
\hline Chenopodium murale & Nettle-leaf goosefoot & & $\mathrm{i}$ & $r$ & & & & & & & & & & & \\
\hline C. pumilio & Small crumbweed & & & $\mathrm{c}$ & $\mathrm{c}$ & & & & & & & $r$ & & o & \\
\hline Rhagodia candolleana & Coast saltbush & $\mathrm{HO}$ & & o & 0 & c & o & & o & $\mathrm{c}$ & 0 & o & $r$ & $c$ & o \\
\hline Sarcocornia quinqueflora & Beaded glasswort & $\mathrm{HO}$ & & & & & & & & & $\mathrm{c}$ & c & & & \\
\hline Suaeda australis & Seablite & & & & & & & & & & o & & & & \\
\hline $\begin{array}{l}\text { Threlkeldia diffusa } \\
\text { CONVOLVULACEAE }\end{array}$ & Coast bonefruit & $\mathrm{HO}$ & & & & & o & & & & & & & & \\
\hline $\begin{array}{l}\text { Dichondra repens } \\
\text { CRASSULACEAE }\end{array}$ & Kidney weed & & & c & c & & $\mathrm{c}$ & & $\mathrm{r}$ & & & r & $c$ & c & r \\
\hline Crassula belmsii & Swamp stonecrop & & & & & & & & o & & & & & & \\
\hline $\begin{array}{l}\text { C. sieberana subsp. tetramer } \\
\text { EPACRIDACEAE }\end{array}$ & ra Austral stonecrop & & & & & & & & $\mathrm{c}$ & & & & & & \\
\hline $\begin{array}{l}\text { Leucopogon parviflorus } \\
\text { Monotoca elliptica } \\
\text { EUPHORBIACEAE }\end{array}$ & $\begin{array}{l}\text { Coastal beard heath } \\
\text { Tree broom-heath }\end{array}$ & $\mathrm{HO}$ & & & & & $\begin{array}{l}\mathrm{c} \\
\mathrm{o}\end{array}$ & 0 & $\mathrm{r}$ & $\mathrm{c}$ & & $r$ & & & o \\
\hline $\begin{array}{l}\text { Euphorbia paralias } \\
\text { FABACEAE }\end{array}$ & Sea spurge & & $\mathrm{i}$ & & & & & & & & o & c & & & \\
\hline Medicago lupulina & Black medic & $\mathrm{HO}$ & $\mathrm{i}$ & o & o & & & & & & & & & & \\
\hline M. polymorpha & Burr medic & $\mathrm{HO}$ & $\mathrm{i}$ & 0 & o & & & & & & & & & & \\
\hline Melilotus albus & Bokhara clover & & $\mathrm{i}$ & c & $\mathrm{c}$ & & & & & & & $r$ & o & c & \\
\hline Swainsona lessertiifolia & Poison pea & & & & & & & & $\mathrm{r}$ & & & $r$ & & & \\
\hline Trifolium campestre & Hop clover & $\mathrm{HO}$ & $\mathrm{i}$ & r & r & & r & & & & & $\mathbf{r}$ & & $r$ & \\
\hline T. dubium & Yellow suckling clover & $\mathrm{HO}$ & $\mathrm{i}$ & $\mathrm{r}$ & $\mathrm{r}$ & & & & & & $\mathrm{r}$ & & $r$ & $r$ & \\
\hline T. fragiferum & Strawberry clover & & $\mathrm{i}$ & o & & & & & & & & & & & \\
\hline Ulex europaeus & Gorse & & $\mathrm{i}$ & & & & & & & & & & & & \\
\hline $\begin{array}{l}\text { Vicia sativa } \\
\text { FRANKENIACEAE }\end{array}$ & Common vetch & $\mathrm{HO}$ & $\mathrm{i}$ & & & & & & & & & o & & & \\
\hline $\begin{array}{l}\text { Frankenia pauciflora } \\
\text { GENTIANACEAE }\end{array}$ & Sea heath & $\mathrm{HO}$ & 5 & & & & & & & & & $r$ & & & \\
\hline Centaurium erythraea & Common centaury & & $\mathrm{i}$ & $r$ & $r$ & & & & & & & & & $\mathbf{r}$ & \\
\hline $\begin{array}{l}\text { Sebaea albidiflora } \\
\text { GERANIACEAE }\end{array}$ & White sebaea & $\mathrm{HO}$ & & & & & & & & & $\mathrm{r}$ & & & & \\
\hline Erodium sp. & Stork's-bills & & $\mathrm{i}$ & $\mathrm{c}$ & c & & & & & & & $\mathrm{r}$ & & $\mathrm{c}$ & \\
\hline Geranium molle & Dove's-foot crane's-bill & & $\mathrm{i}$ & & & & & & & & $\mathrm{r}$ & r & & & \\
\hline G. potentilloides & Mountain geranium & & & & & & & & & & & $r$ & & & \\
\hline $\begin{array}{l}\text { Pelargonium australe } \\
\text { LAMIACEAE }\end{array}$ & Wild geranium & & & $\mathbf{r}$ & & & & & & & & & & & \\
\hline $\begin{array}{l}\text { Marrubium vulgare } \\
\text { MALVACEAE }\end{array}$ & Horehound & & $\mathrm{i}$ & $r$ & & & & & & & & & & & \\
\hline Lavatera plebeia & Austral hollyhock & & & & & $r$ & & & & & & & & & \\
\hline
\end{tabular}


Where Status/ vouch- distri-

ered bution
Community Types

$\begin{array}{llllllllllll}1 & 2 & 3 & 4 & 5 & 6 & 7 & 8 & 9 & 10 & 11 & 12\end{array}$

\section{MIMOSACEAE}

Acacia ?genistifolia

Acacia sophorae

MYOPORACEAE

Myoporum insulare

MYRTACEAE

Kunzea ambigua

Leptospermum laevigatum

ONAGRACEAE

Epilobium billardierianum Common willowherb OXALIDACEAE

Oxalis perennans

Native oxalis

PITTOSPORACEAE

Bursaria spinosa

PLANTAGINACEAE

Plantago coronopus

POLYGALACEAE

Comesperma volubile

POLYGONACEAE

Acetosella vulgaris

Muehlen beckia adpressa

Rumex bidens

R. brownii

PORTULACEAE

Calandrinia calyptrata

PRIMULACEAE

Anagallis arvensis

Samolus repens

RANUNCULACEAE

Clematis microphylla

ROSACEAE

Acaena novae-zelandiae

RUBIACEAE

Coprosma repens

Galium australe

RUTACEAE

Correa alba var. alba

C. alba X Correa backhouseana

C. reflexa var. reflexa

SANTALACEAE

Exocarpos strictus

Leptomeria drupacea

SCROPHULARIACEAE

Mimulus repens

SOLANACEAE

Lycium ferocissimum

Solanum nigrum

THYMELAECEAE

Pimelea serpyllifolia

URTICACEAE

Urtica urens

ZYGOPHYLLACEAE

Zygophyllum billardierei Scrambling twin-leaf

Creeping monkey-flower

African boxthorn Black-berry nightshade

Thyme rice-flower

Stinging nettle

MONOCOTYLEDONAE

CENTROLEPIDACEAE

Centrolepis strigosa

CYPERACEAE

Isolepis aucklandica

I. cernua

I. nodosa

Buckshorn plantain

Blue love creeper

Sheep sorrel

Climbing lignum

Mud dock

Slender dock

Pink purslane

Scarlet pimpernel

Creeping brookweed

Small-leaf clematis

Buzzy

Mirror bush

Tangled bedstraw

White correa
Common correa

Dwarf cherry
Currant bush

Hairy centrolepis

Club-rush

Grassy club-rush
Early wattle

Coast wattle

Boobyalla $\mathrm{HO}$

$\mathrm{HO}$

Fringe myrtle

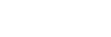

-

2

$\mathrm{HO}$

$\mathrm{HO}$

MEL

MEL

MEL

$\mathrm{HO}$

o

i

o

$\begin{array}{ll}0 & 0 \\ 0 & 0\end{array}$

-

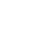
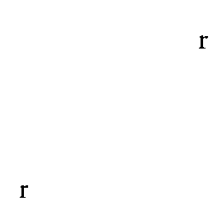

r

o

r

o

$\begin{array}{ll}\mathrm{i} & \mathrm{o} \\ \mathrm{i} & \mathrm{r}\end{array}$

o

C $0 \quad 0$

o c

o

5

$\mathrm{HO}$

$\mathrm{HO}$ 


\begin{tabular}{|c|c|c|c|c|c|c|c|c|c|c|c|c|c|c|c|}
\hline & & \multirow{2}{*}{\multicolumn{2}{|c|}{$\begin{array}{l}\text { Where Status/ } \\
\text { vouch- distri- } \\
\text { ered bution }\end{array}$}} & \multicolumn{12}{|c|}{ Community Types } \\
\hline & & & & 1 & 2 & 3 & 4 & 5 & 6 & 7 & 8 & 9 & 10 & 11 & 12 \\
\hline Lepidosperma gladiatum & Coast sword sedge & $\mathrm{HO}$ & & $c$ & $\mathrm{c}$ & & o & & & o & & o & & & o \\
\hline $\begin{array}{l}\text { Schoenoplectus pungens } \\
\text { JUNCACEAE }\end{array}$ & American club-rush & $\mathrm{HO}$ & & $\mathrm{r}$ & & & & & & & 0 & & & & \\
\hline Juncus kraussii & Sea rush & $\mathrm{HO}$ & & 0 & o & & & & & & 0 & & & & \\
\hline $\begin{array}{l}\text { J. pallidus } \\
\text { LILIACEAE }\end{array}$ & Pale rush & & & o & & & & & & & & & & & \\
\hline Bulbine semibarbata & Leek lily & & & & & & & & $\mathrm{c}$ & & 0 & o & & & \\
\hline Dianella brevicaulis (Ostenf.) & & & & & & & & & & & & & & & \\
\hline G.W. Carr \& P.F. Horsfall & Coastal flax-lily & & & & & & & & o & & & & & & $\mathrm{r}$ \\
\hline D. revoluta & Spreading flax-lily & $\mathrm{HO}$ & & $\mathrm{r}$ & & & $r$ & & & & & & & & \\
\hline D. tasmanica & Tasman flax-lily & & & & & & $\mathrm{r}$ & & & & & & & & \\
\hline ORCHIDACEAE & & & & & & & & & & & & & & & \\
\hline $\begin{array}{l}\text { Microtis unifolia } \\
\text { POACEAE }\end{array}$ & ommon onion orchid & & & $c$ & & & & & & & & & & & \\
\hline Agrostis aemula var. aemula & Blown grass & & 5 & & & & & & $\mathrm{r}$ & & & & & & \\
\hline Aira caryophyllea & Silvery hair grass & $\mathrm{HO}$ & $\mathrm{i}$ & 0 & & & $r$ & & & & & & & & \\
\hline A. praecox & Early hair grass & & $\mathrm{i}$ & & & & & & o & & & & & & \\
\hline Austrofestuca littoralis & Coast fescue & $\mathrm{HO}$ & & & & & & c & & & & $\mathrm{r}$ & & & \\
\hline Austrostipa flavescens & Yellow spear grass & $\mathrm{HO}$ & & & & & o & & & & & & & & \\
\hline A. stipoides & Coastal spear grass & $\mathrm{HO}$ & & & & & & & & & & o & c & & \\
\hline Bromus diandrus & Great brome & $\mathrm{HO}$ & $\mathrm{i}$ & $\mathrm{c}$ & $\mathrm{c}$ & & $\mathrm{r}$ & & $\mathrm{r}$ & & & & & $\mathrm{c}$ & \\
\hline B. hordeaceus & Soft brome & $\mathrm{HO}$ & $\mathrm{i}$ & $\mathrm{c}$ & $\mathrm{c}$ & & & & & & & & & c & \\
\hline Catapodium rigidum & Fern grass & $\mathrm{HO}$ & $\mathrm{i}$ & $\mathrm{r}$ & $r$ & & $\mathrm{r}$ & & $\mathrm{r}$ & & & & & $\mathrm{r}$ & \\
\hline Dactylis glomerata & Cocksfoot & & $\mathrm{i}$ & $r$ & $r$ & & & & & & & & & & \\
\hline Dichelachne crinita & Long-hair plume grass & & & $\mathrm{r}$ & & & $r$ & & o & & & & $\mathrm{r}$ & & \\
\hline Distichlis distichophylla & Australian salt grass & $\mathrm{HO}$ & & o & o & & & & & & c & $\mathrm{c}$ & o & & \\
\hline Holcus lanatus & Yorkshire fog grass & $\mathrm{HO}$ & $\mathrm{i}$ & $\mathrm{r}$ & $r$ & & & & & & & & & $\mathrm{r}$ & \\
\hline Hordeum murinum ssp. glaucu & «cum Wild barley & & $\mathrm{i}$ & $\mathrm{r}$ & & & & & & & & & & & \\
\hline Lagurus ovatus & Hare's-tail & $\mathrm{HO}$ & $\mathrm{i}$ & $\mathrm{C}$ & $c$ & & $\mathrm{c}$ & & o & & $\mathrm{r}$ & $\mathrm{c}$ & & $\mathrm{c}$ & o \\
\hline Lolium perenne & Perennial ryegrass & $\mathrm{HO}$ & $\mathrm{i}$ & & & & & & & & o & & & & \\
\hline Parapholis incurva & Curly ryegrass & $\mathrm{HO}$ & $\mathrm{i}$ & & & & & & o & & & & & & \\
\hline Phragmites australis & Common reed & $\mathrm{HO}$ & & & & & & & & & $\mathbf{r}$ & & & & \\
\hline Poa poiformis & Blue tussock grass & $\mathrm{HO}$ & & $\mathrm{c}$ & $\mathrm{c}$ & o & o & & o & $\mathbf{r}$ & $\mathrm{r}$ & o & & $\mathrm{c}$ & \\
\hline Polypogon monspeliensis & Annual beard-grass & & $\mathrm{i}$ & $\mathrm{r}$ & & & & & & & & & & & \\
\hline Rytidosperma dimidiatum Lo & Long-hair plume grass & & & & & & & & & & & $\mathrm{r}$ & & & \\
\hline Spinifex sericeus & Coastal spinifex & $\mathrm{HO}$ & & & & & & c & & & & & & & \\
\hline Stenotaphrum secundatum & Buffalo grass & & $\mathrm{i}$ & $r$ & & & & & & & & & & & \\
\hline PTERIDOPHYTA & & & & & & & & & & & & & & & \\
\hline ASPLENIACEAE & & & & & & & & & & & & & & & \\
\hline $\begin{array}{l}\text { Asplenium obtusatum } \\
\text { DENNSTAEDTIACEAE }\end{array}$ & Shore spleenwort & $\mathrm{HO}$ & & & & & & & $r$ & & & & & & \\
\hline Pteridium esculentum & Austral bracken & & & & & & & & $\mathrm{r}$ & & & & & & \\
\hline POLYPODIACEAE & & & & & & & & & & & & & & & \\
\hline Microsorum pustulatum & Kangaroo fern & & & & & & & & $\mathrm{r}$ & & & & & & \\
\hline
\end{tabular}

